\title{
Can Aggregate Production Planning (APP) Be Modified to Be as Good as Master Production Scheduling (MPS)?
}

\author{
Thorsten Vitzthum ${ }^{1}$; Thorsten Claus ${ }^{2}$; Frank Herrmann ${ }^{3}$ \\ ${ }^{1,2}$ Technische Universität Dresden (TU Dresden) \\ Faculty of Business and Economics, \\ International Institute Zittau \\ Markt 23, 02763 Zittau, Germany \\ ${ }^{3}$ Ostbayerische Technische Hochschule Regensburg (OTH Regensburg) \\ Faculty of Computer Science and Mathematics \\ Innovation and Competence Center for Production Logistics and Factory Planning (IPF) \\ Prüfeninger Str. 58, 93049 Regensburg, Germany \\ e-mail: ${ }^{1}$ thorsten.vitzthum@tu-dresden.de; ${ }^{2}$ thorsten.claus@tu-dresden.de; \\ frank.herrmann@oth-regensburg.de
}

\begin{abstract}
In this paper, the significance of master production scheduling (MPS) for hierarchical production planning should be brought out. Therefore, several modifications of aggregate production planning (APP) are made and realization of the planning results of APP and MPS are compared. The goal is to improve the realization of APP in such a way that the realization is as good as the realization of MPS. Improvements for individual planning situations could be achieved, but no general solution could be found. Especially the use of a suitable capacity reduction factor (CRF) combined with the consideration of lead time leads to an improvement of the solution. However, finding a suitable CRF for more than one product is difficult. This usually depends on the underlying demand profile and must be re-determined for each constellation.
\end{abstract}

\section{Keywords}

Hierarchical production planning; Aggregate production planning (APP); Master production scheduling (MPS); Material requirement planning; Resource profiles.

\section{Introduction}

Production planning is a very complex. A high number of parameters and their multiple dependencies are simultaneously to be taken into account. This resulting planning problem can't be solved in an appropriate time even with most powerful computers and sophisticated software [1].

In the most commercial production planning and control systems, the complex planning of production planning is replaced by the hierarchical production planning approach [6]. In this case the complex singular problem is decomposed in several manageable problems. These problems are solved successively and the individual solutions are combined into one overall solution at the end. The hierarchical production planning approach is attributed to Hax and Meal in the year 1975 [5]. Drexl, Fleischmann, Günther and Stadler suggested in 1994 to expand this concept by limited capacities of resources [2]. On this planning concept, the paper is based. Typical hierarchical production planning is shown in Figure 1. 


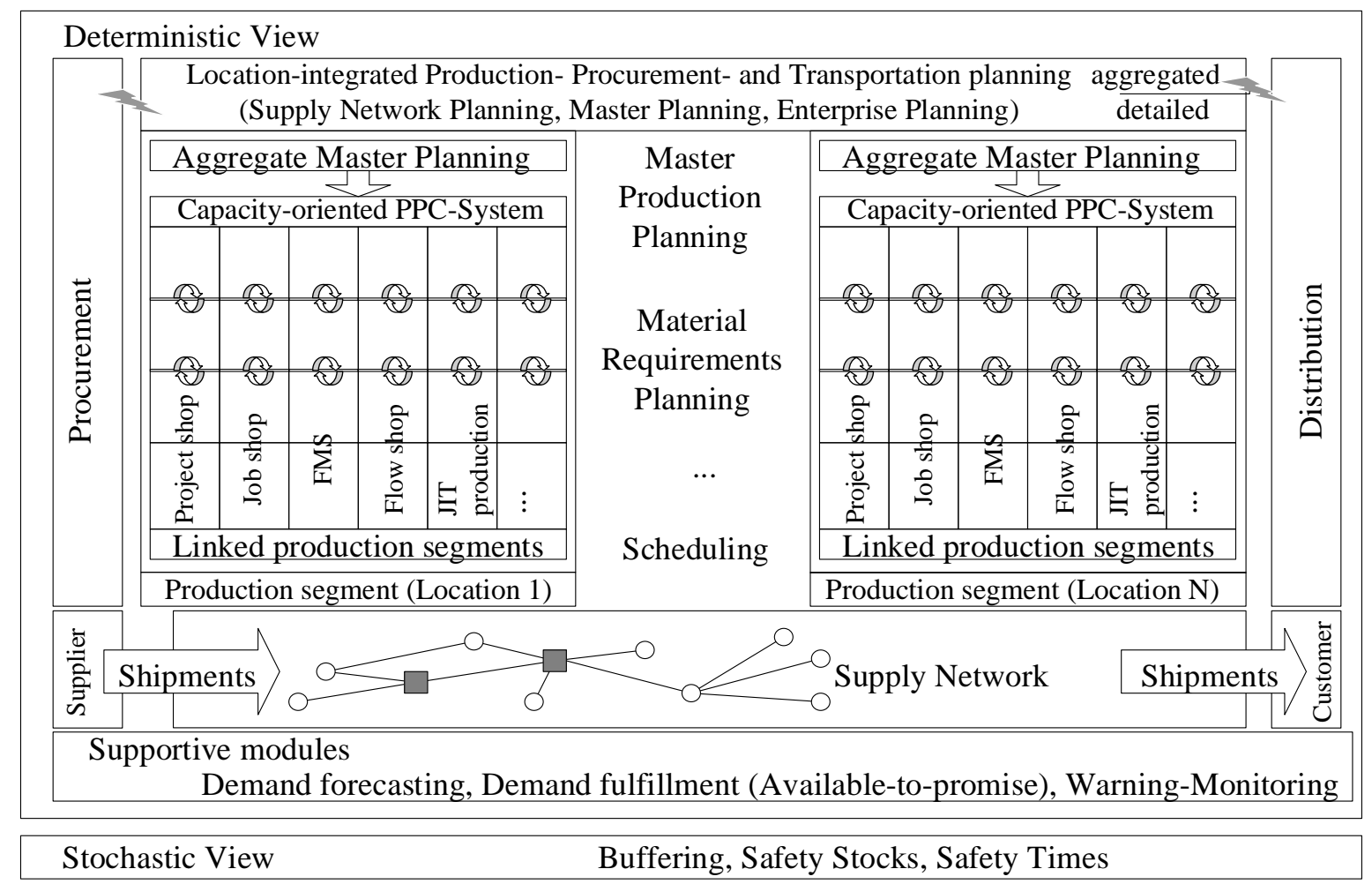

Source: [4]

Fig. 1: Typical hierarchical production planning

Aggregation plays an important role in this planning approach. There are three different types of aggregation. The aggregation of time especially the period size, decision variables like grouping of products or constraints like grouping of machines to work centers or production sites [3][7]. This planning concept consists of the following steps: Aggregate production planning (APP), master production scheduling (MPS), material requirements planning and scheduling.

APP predicts the planned independent requirements for one production site on a product group level based on demand forecasts. MPS predicts the planned independent requirements for final products for a production site. Therefore, product groups are disaggregated into final products. Through the use of resource profiles production lead time and the capacity requirements for each work center is considered [9].

In the paper Evidence of the relevance of master production Scheduling for hierarchical Production Planning [8] the relevance of MPS was demonstrated through a case study. MPS can avoid shortages through a closer examination of the capacity. It was suggested to introduce a capacity restriction and to consider the exact offset periods on APP level to possibly avoid shortages. This will be carried out. Capacity on APP level will be reduced by a capacity reduction factor (CRF).

The point of this paper is best illustrated by following a clear example from a case study. At the beginning of the case study solution and realization of APP and MPS are compared. In the next step, a CRF for APP is introduced and the exact offset periods are considered. In the end, it is examined what happens if total demand for all products is the same, but the demand for each product is different. 


\section{$1 \quad$ Case Study}

One production site with two work centers is considered. The capacity of each work center is 500 hours per period. So, the production site has a capacity of 1000 hours per period. Human capacity is equal technical capacity and there is no additional capacity. In order to be able to compare results which each other, the period size of aggregate production planning (APP) and master production scheduling (MPS) is the same and it is assumed that the predicted planned independent requirements are identical to the real customer requirements. The derived requirements to all components are produced just in time. The model of a closed production is used. Closed production is characterized by the fact that each planned order must be finished and stored, before it can be further processed or shipped [6].

Two product groups which are produced in one production site are considered. Each product group consists of one final product. The final product (E) needs 3 hours of capacity per unit in work center (A) and the component (V) needs 7 hours of capacity per unit in work center (B). It follows that product group $(\mathrm{P})$ needs 10 hours of capacity per unit in production site. The final product $(\mathrm{F})$ needs 5 hours of capacity per unit in work center $(\mathrm{A})$ and the component $(\mathrm{V})$ needs 5 hours of capacity per unit in work center (B). It follows that product group (Q) needs also 10 hours of capacity per unit in production site. The estimated lead time for all products and components is 1 period. Set-up times and costs are not considered.

The planning horizon of the case study starts in period 1 and ends with the last customer demand in period 10 . The demands of product group $(\mathrm{P})$ respectively product $(\mathrm{E})$ and product group $(\mathrm{Q})$ respectively product $(\mathrm{F})$ are shown in Table 1 .

Tab. 1: Demand for the case study

\begin{tabular}{|l|r|r|r|r|r|r|r|r|r|c|c|}
\hline Period (t) & \multicolumn{1}{|c|}{$\mathbf{1}$} & \multicolumn{1}{|c|}{$\mathbf{3}$} & $\mathbf{4}$ & $\mathbf{5}$ & $\mathbf{6}$ & $\mathbf{7}$ & $\mathbf{8}$ & $\mathbf{9}$ & $\mathbf{1 0}$ & $\sum$ \\
\hline Demand $\left(d_{E, t}^{A}\right)[$ units $]$ & 0 & 0 & 0 & 0 & 40 & 50 & 60 & 50 & 40 & 60 & 300 \\
\hline Demand $\left(d_{F, t}^{A}\right)[$ units] & 0 & 0 & 0 & 0 & 40 & 50 & 60 & 50 & 40 & 60 & 300 \\
\hline
\end{tabular}
Source: Own

As shown in [8] due to the aggregated consideration of capacity requirement for product groups, APP overestimates the number of products which can be produced into one period. This was shown for one product group which is related to one final product. To avoid this CRF of 0.83 is introduced in combination with the consideration of the lead time of 2 periods. The solution and the realization of this APP is as good as the one of MPS.

The Solution for APP with a CRF of 0.83 and MPS is shown in Table 2. The objective is $€ 872$.

Tab. 2: Solution of APP with capacity reduction factor 0.83 and MPS

\begin{tabular}{|l|r|r|r|r|r|r|r|r|c|c|c|}
\hline Period (t) & \multicolumn{1}{|c|}{$\mathbf{1}$} & \multicolumn{1}{|c|}{$\mathbf{3}$} & \multicolumn{1}{|c|}{$\mathbf{4}$} & \multicolumn{1}{c|}{$\mathbf{5}$} & \multicolumn{1}{|c|}{$\mathbf{1}$} & \multicolumn{1}{c|}{$\mathbf{8}$} & \multicolumn{1}{c|}{$\mathbf{9}$} & \multicolumn{1}{c|}{$\mathbf{0}$} & $\sum$ \\
\hline$d_{E, t}^{A}$ [units] & 0 & 0 & 0 & 0 & 80 & 100 & 120 & 100 & 80 & 120 & 600 \\
\hline$x_{E, t}^{A}$ [units] & 0 & 19 & 83 & 83 & 83 & 83 & 83 & 83 & 83 & 0 & 600 \\
\hline$y_{E, t}^{E}$ [units] & 0 & 0 & 19 & 102 & 105 & 88 & 51 & 34 & 37 & 0 & 436 \\
\hline
\end{tabular}

Source: Own

The solution can be realized without exceeding the period capacity and no shortage occurs in the individual periods.

\section{$2 \quad$ Results of the Research}

In this case study, the planning results for two product groups as described in the case study are compared. First the Solution for APP which is provided by ILOG is presented. Next, an 
optimal solution for APP without shortages and delay is searched and presented. At the end the results are compared with the results of MPS.

Tab. 3: Solution of APP with CRF 0.83 (ILOG)

\begin{tabular}{|l|r|r|r|r|r|c|c|c|c|c|c|}
\hline Period (t) & \multicolumn{1}{c|}{$\mathbf{2}$} & \multicolumn{1}{c|}{$\mathbf{3}$} & $\mathbf{4}$ & $\mathbf{5}$ & $\mathbf{6}$ & $\mathbf{7}$ & $\mathbf{8}$ & $\mathbf{9}$ & $\mathbf{1 0}$ & $\sum$ \\
\hline$d_{P, t}^{A}$ [units] & 0 & 0 & 0 & 0 & 40 & 50 & 60 & 50 & 40 & 60 & 300 \\
\hline$x_{P, t}^{A}$ [units] & 0 & 19 & 0 & 21 & 83 & 27 & 50 & 77 & 23 & 0 & 300 \\
\hline$y_{P, t}^{E}$ [units] & 0 & 0 & 19 & 19 & 0 & 33 & 0 & 0 & 37 & 0 & 108 \\
\hline$d_{Q, t}^{A}$ [units] & 0 & 0 & 0 & 0 & 40 & 50 & 60 & 50 & 40 & 60 & 300 \\
\hline$x_{Q, t}^{A}$ [units] & 0 & 0 & 83 & 62 & 0 & 56 & 33 & 6 & 60 & 0 & 300 \\
\hline$y_{Q, t}^{E}$ [units] & 0 & 0 & 0 & 83 & 105 & 55 & 51 & 34 & 0 & 0 & 328 \\
\hline $\operatorname{Sum} x_{P, t}^{A}+x_{Q, t}^{A}$ & 0 & 19 & 83 & 83 & 83 & 83 & 83 & 83 & 83 & 0 & 600 \\
\hline
\end{tabular}

Source: Own

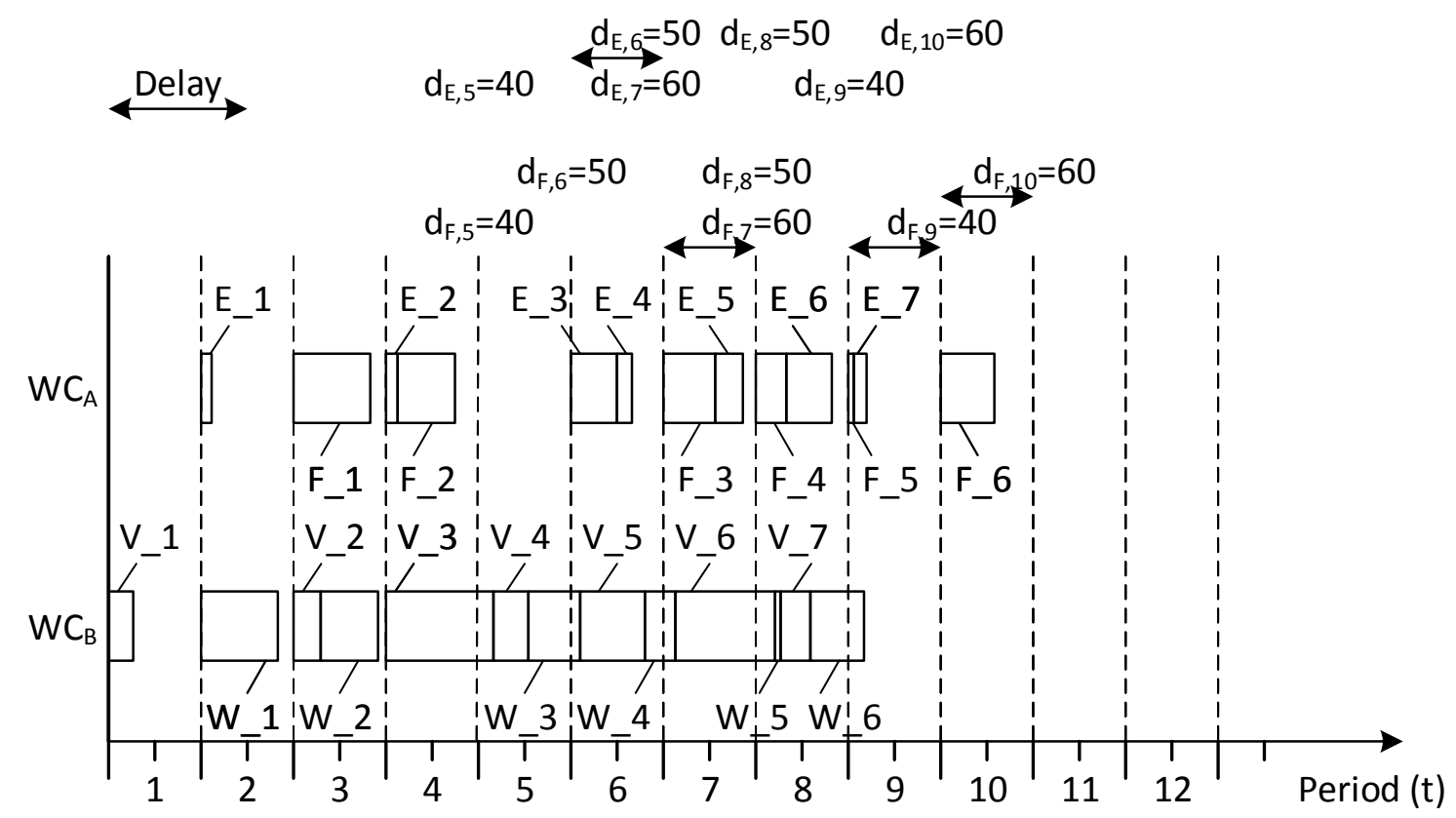

Source: Own

Fig. 2: Realization of APP with CRF 0.83 (ILOG)

In Figure 2 the realization of Table 3 is illustrated as Gantt chart. The lead time is taken into account during the realization. Figure 2 shows that the demand of product $(E)$ of period 6 is fulfilled with 1 period delay. The same behavior can be seen for the demand of product $(\mathrm{F})$ of the periods 7, 9 and 10. The total delay in periods is 4 . Besides the total shortage of 510 units the inventory holding costs increase from $€ 872$ to $€ 1266$. ILOG finds an optimal solution. This may not be the only solution, there may be other solutions. Another solution is shown in Table 4 and the realization is illustrated in Figure 3. This solution can be realized without shortage and delay. The inventory holding costs correspond to the objective of $€ 872$. Both solutions have in common that a maximum of 83 units of both products can be produced per period. The exact production quantities can be found in tables under "Sum $x_{P, t}^{A}+x_{Q, t}^{A}$ ".

Furthermore, the results are compared with the solution and realization of the case study with one product group shown in the paper of Vitzthum \& Herrmann [8]. We see that in this case study we have the same production quantities and the same inventory holding costs of $€ 872$. 
Tab. 4: Solution of APP with CRF 0.83 (alternative)

\begin{tabular}{|c|c|c|c|c|c|c|c|c|c|c|c|}
\hline Peri & $\mathbf{1}$ & 2 & 3 & 4 & 5 & 6 & 7 & 8 & 9 & 10 & $\sum$ \\
\hline$d_{P, t}^{A}$ & 0 & 0 & 0 & 0 & 40 & 50 & 60 & 50 & 40 & 60 & 300 \\
\hline$x_{P, t}^{A}$ [units] & 0 & 6 & 42 & 42 & 42 & 42 & 42 & 42 & 42 & 0 & 300 \\
\hline$y_{P, t}^{E}$ [units] & 0 & 0 & 6 & 48 & 50 & 42 & 24 & 16 & 18 & U & 204 \\
\hline$d_{Q, t}^{A}[\mathrm{u}$ & 0 & 0 & U & U & 40 & 50 & 60 & 50 & 40 & 60 & 300 \\
\hline$x_{Q, t}^{A}[$ & 0 & 13 & 41 & 41 & 41 & 41 & 41 & 41 & 41 & J & 300 \\
\hline$y_{Q, t}^{E}[$ & 0 & 0 & 13 & 43 & 55 & 46 & 27 & 18 & 19 & 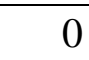 & 232 \\
\hline $\operatorname{Sum} x_{P, t}^{A}+x$ & 0 & 19 & 83 & 83 & 83 & 83 & 83 & 83 & 83 & 0 & 600 \\
\hline
\end{tabular}

Source: Own

$$
\begin{array}{r}
d_{E, 5}=40 \quad d_{E, 6}=50 \quad d_{E, 8}=50 \quad d_{E, 10}=60 \\
d_{E, 9}=40 \\
d_{F, 5}=40 \quad d_{F, 7}=60 \quad d_{F, 8}=50 \quad d_{F, 10}=60
\end{array}
$$

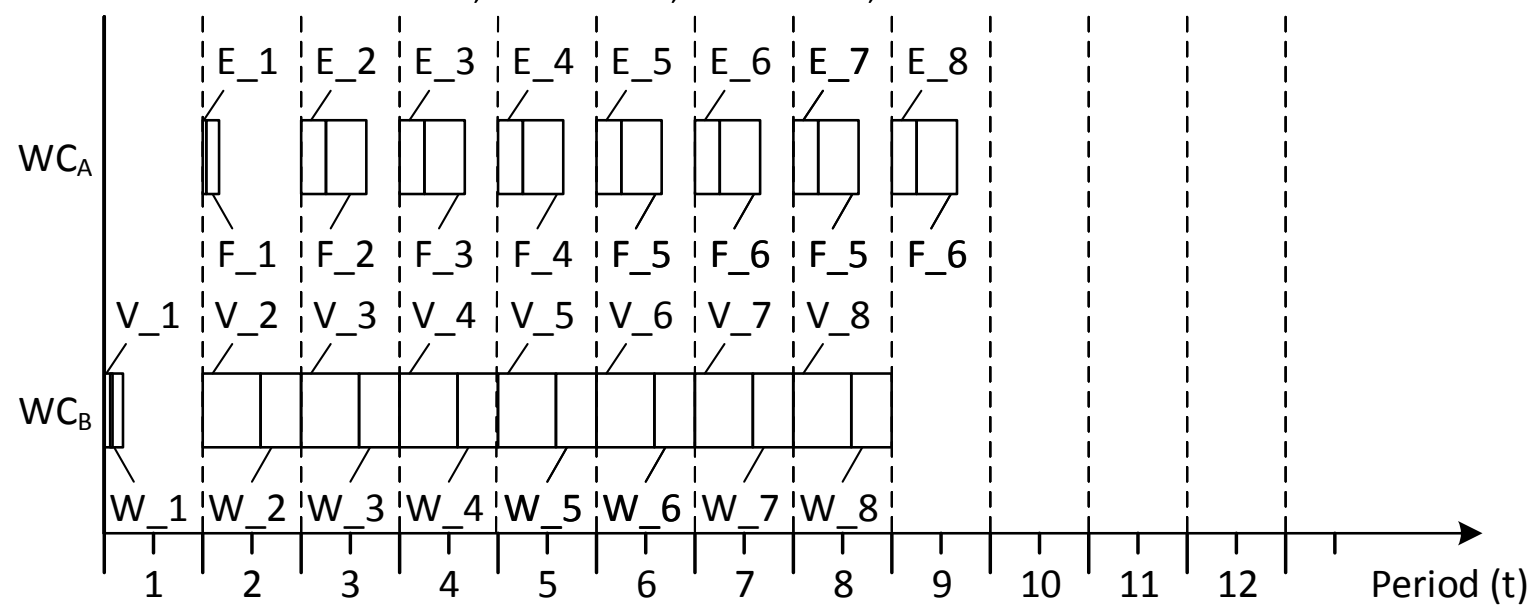

Source: Own

Fig. 3: Realization of APP with CRF 0.83 (alternative)

Finally, the results of the APP are compared with the results of the MPS. The results of the MPS are shown in Table 5 and illustrated in Figure 4.

\begin{tabular}{|c|c|c|c|c|c|c|c|c|c|c|c|}
\hline Period $(t)$ & 1 & 2 & 3 & 4 & 5 & 6 & 7 & 8 & 9 & 10 & $\sum$ \\
\hline$d_{E, t}^{A}$ [units] & 0 & 0 & 0 & 0 & 40 & 50 & 60 & 50 & 40 & 60 & 300 \\
\hline$x_{E, t}^{A}$ [units] & 0 & 15 & 71 & 42 & 35 & 30 & 35 & 42 & 30 & 0 & 300 \\
\hline$y_{E, t}^{E}$ [units] & 0 & 0 & 15 & 86 & 88 & 73 & 43 & 28 & 30 & 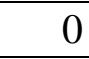 & 363 \\
\hline$d_{F, t}^{A}[\mathrm{l}$ & 0 & 0 & 0 & 0 & 40 & 50 & 60 & 50 & 40 & 60 & 300 \\
\hline$x_{F, t}^{A}[\mathrm{l}$ & 0 & 0 & 0 & 41 & 51 & 58 & 51 & 41 & 58 & 0 & 300 \\
\hline$y_{F, t}^{E}[$ & 0 & & & & & & 0 & & & & 6 \\
\hline $\operatorname{Sum} x_{E, t}^{A}+x_{F}^{A}$ & 0 & 15 & 71 & 83 & 86 & 88 & 86 & 83 & 88 & 0 & 600 \\
\hline
\end{tabular}

Tab. 5: Solution of MPS

Source: Own 


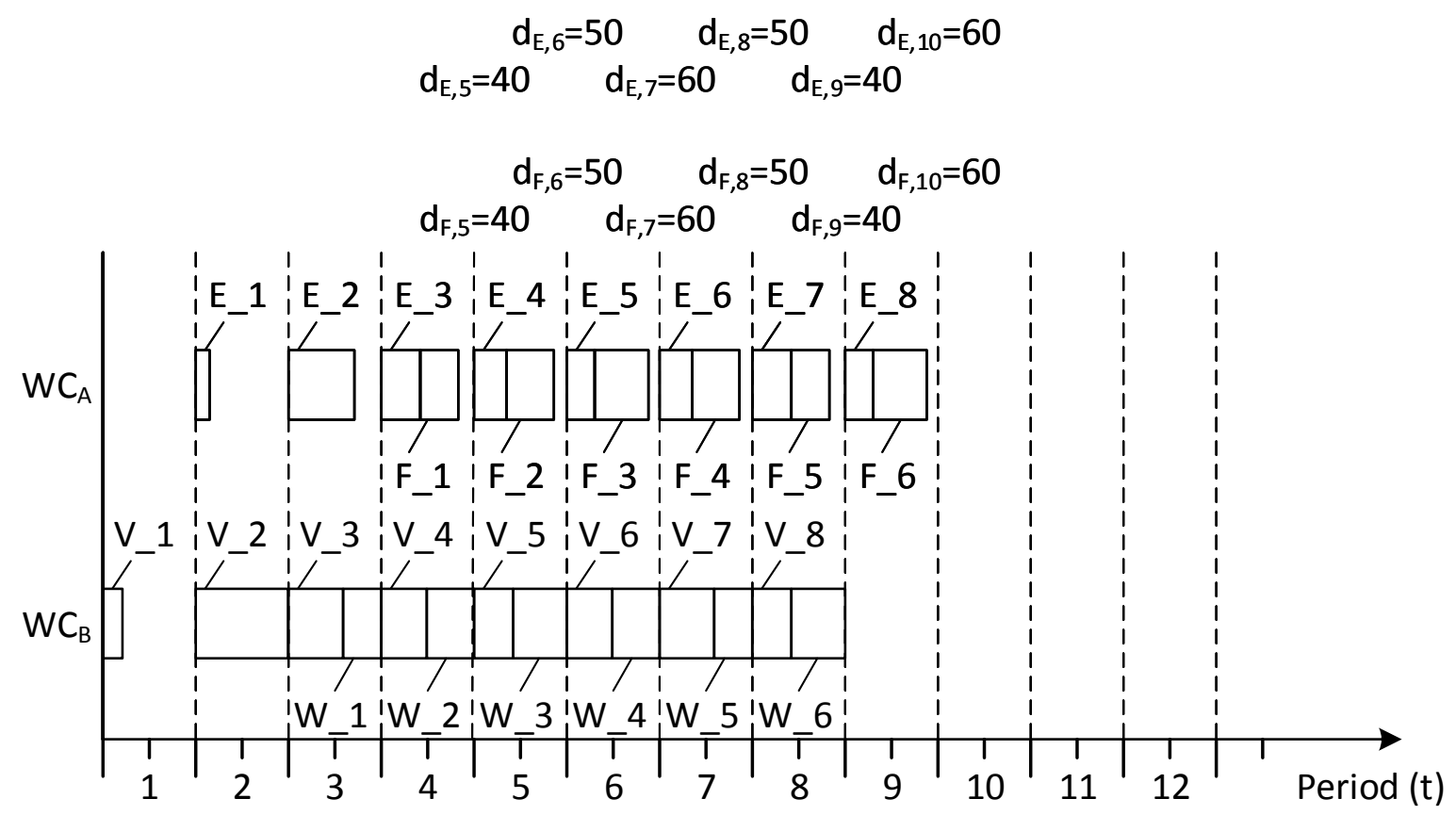

Source: Own

\section{Fig. 4: Realization of MPS}

The realization can be done without shortage and delay. The inventory holding costs are $€ 738$. Compared to the APP, the storage costs have decreased by $€ 134$. This means a saving of $15.37 \%$. In order to understand the differences, the planed independent requirements of APP and MPS have to be compared. APP has a maximum of 83 units which can be produced independently of the product which is produced. MPS has a maximum of 88 units, but it depends on the product mix, which is produced.

\section{Discussion}

One advantage of MPS is the consideration of lead time. But even if APP takes lead time into account, we do not get any plans that can be realized without shortages and delay. APP estimates the available capacity of the work center wrongly, because of the aggregated planning for the production site. Normally APP overestimates the available capacity. One way to correct this is CRF. A good chosen CRF will provide feasible plans. Due to the general reduction, a rough estimate is made. There is no differentiation of capacity requirements by products. The main advantage of the MPS is the use of resource profiles. A resource profile gives information about the capacity requirements for final products in terms of work centers and offset periods. For this reason, the capacity for the production program is taken into account more precisely. The fact is best demonstrated in comparison of the maximum production rate by product. While APP doesn't differ between product (E) and product (F) and has maximum production rate of 83 units the MPS differs and has a maximum production rate of 71 units for product (E) and a maximum production rate of 100 for product $(F)$.

\section{Conclusion}

MPS is superior to APP due to the detailed consideration of the capacity requirement. Through the use of resource profiles an allocation of the capacity requirement by work center and period based on products is made, while APP has a fixed production rate for all products. MPS has a variable production rate for the products which differs by the product mix of the production program. For this reason MPS can use the available capacity more efficiently than APP. 


\section{Literature}

[1] CLAUS, T.; HERRMANN, F.; MANITZ, M. (eds.): (2015). Produktionsplanung und steuerung: Forschungsansätze, Methoden und deren Anwendungen. Berlin, Heidelberg: Springer Gabler.

[2] DREXL, A.; FLEISCHMANN, B.; GÜNTHER, H.-O.; STADTLER, H.; TEMPELMEIER, H.: (1994). Konzeptionelle Grundlagen kapazitätsorientierter PPSSysteme. Zeitschrift für betriebswirtschaftliche Forschung. Vol. 46, pp. 1022-1045.

[3] GEBHARD, M.: (2009). Hierarchische Produktionsplanung bei Unsicherheit. 1. Auflage. Wiesbaden: Springer Gabler. DOI: 10.1007/978-3-8349-8227-8

[4] GÜNTHER, H.-O.; TEMPELMEIER, H.: (2014). Produktion und Logistik: Supply Chain und Operations Management. 11. Auflage. Norderstedt: Books on Demand. ISBN 978-3735721952.

[5] HAX, A. C.; MEAL, H. C.: (1975). Hierarchical Integration of Production Planning and Scheduling. In: M. A. Geisler (ed.) TIMS studies in the management sciences. Vol. 1. Logistics. pp. 53-69. Amsterdam u.a.: North-Holland.

[6] HERRMANN, F.: (2011). Operative Planung in IT-Systemen für die Produktionsplanung und -steuerung: Wirkung, Auswahl und Einstellhinweise von Verfahren und Parametern. [Mit Online-Service] 1. Auflage. Wiesbaden: Vieweg + Teubner.

[7] STADTLER, H.: (1988). Hierarchische Produktionsplanung bei losweiser Fertigung. Physica-Schriften zur Betriebswirtschaft. Vol. 23. Heidelberg: Springer.

[8] VITZTHUM, T.; HERRMANN, F.: (2017). Evidence of the relevance of master production Scheduling for hierarchical Production Planning. In: Proceedings of the $31^{\text {th }}$ European Conference on Modelling and Simulation, ECMS 2017. pp. 475-481. ISBN 978-0-9932440-4-9. DOI: $10.7148 / 2017-0475$

[9] VOLLMANN, T. E.; BERRY, W. L.; WHYBARK, D. C.; JACOBS, F. R.: (2004). Manufacturing planning and control for supply chain management. $5^{\text {th }}$ ed. McGrawHill international editions. Boston, Mass.: McGraw-Hill. ISBN 978-0072299908. 


\section{MƯŽE BÝT AGREGOVANÉ PLÁNOVÁNÍ PRODUKCE MODIFIKOVÁNO TAK, ABY BYLO TAK DOBRÉ JAKO PLÁNOVÁNÍ PROGRAMU HLAVNÍ PRODUKCE?}

V tomto příspěvku je pomocí případové studie zdůrazněn význam plánování programu hlavní produkce pro hierarchické plánování produkce. Je učiněn pokus o zlepšení výsledku agregovaného celkového plánování změnou jednotlivých parametrů tak, aby to odpovídalo výsledku plánování programu hlavní produkce. V rámci šetření se tak docílilo některých zlepšení jednotlivých situací plánování, avšak obecné řešení se ještě nepodařilo nalézt. Zvláště použití vhodného faktoru k redukci kapacity ve spojení se zohledněním průběhu vede ke zlepšení výsledku. Při plánování více produktů je však těžké najít vhodný faktor pro redukci kapacity, protože ten je odvislý od poptávky.

\section{KANN DIE AGGREGIERTE GESAMTPLANUNG SO MODIFIZIERT WERDEN, DASS DAS PLANUNGSERGEBNIS DEM DER HAUPTPRODUKTIONSPROGRAMMPLANUNG ENTSPRICHT?}

In diesem Beitrag wird anhand einer Fallstudie die Bedeutung der Hauptproduktionsprogrammplanung (HPPLAN) für die hierarchische Produktionsplanung herausgearbeitet werden. Dazu wird versucht das Ergebnis der aggregierten Gesamtplanung (AGGRPLAN) durch Veränderung einzelner Paramater so zu verbessern, dass es dem Ergebnis der HPPLAN entspricht. Im Rahmen der Untersuchungen konnten dabei Verbesserungen für einzelne Planungssituationen erzielt werden, eine generelle Lösung konnte jedoch nicht gefunden werden. Insbesondere der Einsatz eines geeigneten Kapazitätsreduktionsfaktors in Verbindung mit der Berücksichtigung der Durchlaufzeit führt zu einer Verbesserung der Lösung. Bei der Planung von mehr als einem Produkt ist allerdings schwierig einen geeigneten Kapazitätsreduktionsfaktor zu finden, da dieser abhängig von der Nachfrage ist.

\section{CZY ZAGREGOWANE PLANOWANIE PRODUKCJI MOŻE ZOSTAĆ ZMODYFIKOWANE TAK, BY BYŁO TAK DOBRE JAK PLANOWANIE PROGRAMU GLÓWNEJ PRODUKCJI?}

W niniejszym opracowaniu na podstawie studium przypadku wskazano znaczenie planowania programu głównej produkcji w hierarchicznym planowaniu produkcji. Podjęto próbę poprawienia wyniku zagregowanego ogólnego planowania poprzez zmianę poszczególnych parametrów, by odpowiadało to wynikowi planowania programu głównej produkcji. W ramach przeprowadzonych badań osiągnięto pewne udoskonalenia poszczególnych sytuacji planowania, jednak nie udało się na razie znaleźć kompleksowego rozwiązania. Wynik poprawia w szczególności zastosowanie odpowiedniego czynnika do zmniejszenia wielkości $\mathrm{w}$ połączeniu z uwzględnieniem przebiegu. Podczas planowania kilku produktów trudno jednak znaleźć odpowiedni czynnik do zmniejszenia wielkości, ponieważ zależny jest on od popytu. 